\title{
Pengikatan Jaminan Pesawat Udara Terkait Dengan Ratifikasi Konvensi Cape Town 2001 Untuk Kepentingan Penerbangan Internasional
}

\author{
Nanda Dwi Rizkia ${ }^{1}$, Yuhelson ${ }^{2}$, Ramlani Lina $\mathrm{S}^{3}$ \\ ${ }^{1}$ Mahasiswa Magister Kenotariatan, Universitas Jayabaya \\ ${ }^{23}$ Dosen Magister Kenotariatan, Universitas Jayabaya \\ Email: nandadwirizkia.law@gmail.com; yuhelson2870@gmail.com; rlinas@pascajayabaya.ac.id
}

Received : 10 Sep 2021 | Revised : 16 Oct 2021 | Accepted : 27 Nop 2021 | Published : 9 Dec 2021

\begin{abstract}
Exorbitant price of an airplane in Indonesia makes it inconvenient for domestic commercial airline companies to buy it in cash, therefore these airline companies need some firm bank and non-bank financial institutions for financial arrangement with a purpose of providing them credit payment with lease agreements, a venture with no option rights are unlikely found by bank or domestic financial institutions that responsible as creditor or lessor because aside from the excessive number of loans, the risk of default is high as well. Normative juridical research method, is a process to find the regulations, principles and doctrines of law in order to response and faced any legal issues, the outcome of research is domestic airlines inclined to choose leasing companies from abroad to get foreign creditors, the government of Indonesia has ratified the 2001 Cape Town Convention with the issuance of Law No. 1 of 2009 concerning Aviation which makes it easier for domestic commercial airlines to procure airplane under the $S G U$ agreement because foreign creditors get legal warranty that have been acknowledged internationally. The convention regulates the creditor or the lessor of the airplane can withdraw directly from the debtor and operate the airplane as a leasing object without any options rights and procedures.
\end{abstract}

Keywords: warranty, airplane, cape town convention

\begin{abstract}
ABSTRAK
Mahalnya harga sebuah pesawat udara di Indonesia menyulitkan perusahaan penerbangan komersial dalam negeri untuk membelinya secara tunai karena itu perusahaan penerbangan tersebut membutuhkan bank dan lembaga keuangan nonbank yang kuat untuk skema pembiayaan yang berupa pemberian kredit dengan perjanjian sewa guna usaha dengan tanpa hak opsi jarang ditemukan bank atau lembaga keuangan dalam negeri yang bertindak sebagai kreditur atau pemberi sewa karena selain tingginya jumlah pinjaman apalagi terjadi wanprestasi risiko kecelakaanya tinggi. metode penelitian yuridis normatif, suatu proses untuk menemukan aturan hukum, prinsip-prinsip hukum maupun doktrin-doktrin hukum guna menjawab isu-isu hukum yang di hadapi, hasil penelitian perusahaan penerbangan dalam
\end{abstract}


negeri memilih leasing company dari luar negeri untuk mendapatkan kreditur asing, pemerintah republic Indonesia telah meratifikasi konvensi cape town 2001 dengan terbitnya undang-undang no.1 tahun 2009 tentang penerbangan yang mempermudah perusahaan penerbangan komersial dalam negeri untuk pengadaan pesawat terbang dengan perjanjian SGU karena kreditur asing mendapatkan jaminan hukum yang telah disepakati secara internasional dalam konvensi itu diatur bahwa kreditur atau pemilik pesawat dapat langsung menarik dari debitur dan menerbangkan pesawat terbang sebagai objek leasing dengan tanpa hak opsi dan prosedur.

Kata Kunci: jaminan, pesawat udara, konvensi cape town

\section{PENDAHULUAN}

Negara Indonesia merupakan Negara kepulauan yang membentang dari kota sabang sampai merauke. Karena itu sangat dibutuhkan transportasi udara sebagai sarana penghubung antar provinsi dan kota-kota yang memiliki airport." Salah satu alat transportasi yang sangat menunjang kegiatan perekonomian di Indonesia adalah pesawat udara yang digunakan dalam penerbangan." Transportasi udara mengalami perkembangan pesat setelah pemerintah memberikan cukup kebebasan bagi maskapai penerbangan untuk menentukan tariff." Kenyataanya perkembangan bisnis transportasi udara tidak seiring dengan perkembangan sistem hukum yang menopang pertumbuhan bisnis sektor tersebut." Salah satunya adalah mengenai jaminan atas pesawat udara yang meliputi pesawat terbang dan helikopter dalam pembiayaan untuk pengadaan pembelian pesawat udara. Hal ini mengakibatkan dalam pelaksanaanya jarang sekali maskapai penerbangan membeli pesawat udara secara tunai seketika dengan menggunakan uang atau modalnya sendiri." Untuk itu dibutuhkan pembiayaan dari pihak lain salah satunya adalah dari pihak bank."1

Salah satu penyediaan dana yang dilakukan bank adalah melalui pemberian fasilitas kredit." Kredit atau pembiayaan yang diberikan oleh bank mengandung resiko. Untuk mengurangi resiko tersebut jaminan pemberian kredit dalam arti keyakinan atas kemampuan dan kesanggupan nasabah/debitor untuk melunasi kewajibannya sesuai yang diperjanjikan merupakan faktor penting yang harus diperhatikan oleh bank. Prinsip kehati-hatian tersebut menjadi bank sebagai sebuah bisnis yang konservatif atau pruden banking terutama disebabkan oleh :

1. Peranan bank yang cukup menentukan dalam perkembangan moneter dan ekonomi secara makro

2. Simpanan dalam bentuk depositi, giro, tabungan dan lain-lain yang berarti suatu bank mempertaruhkan uang rakyat.

3. Karakteristik bisnis bank yang harus selalu sesuai antara dana yang diterima dan dana yang disalurkan sehingga unsur-unsur spekulatif ditekan seminimal mungkin.

Perjanjian kredit di Indonesia belum ada aturan khsusus, oleh karena itu sebagian dasar dari pelaksanaan perjanjian kredit maka perjanjian kredit dikualifikasikan sebagai perjanjian pinjam-meminjam sebagaimana diatur dalam pasal 1769

${ }^{1}$ I Nyoman Ganang Bayu Weda, I Made Sarjana, Suatra Putrawan, Jurnal Kertha Semaya: Vol.02, No.06 (2014), Pengaturan Pesawat Udara Sebagai Obyek Jaminan Kredit, E-ISSN: 2303-0569, https://ojs.unud.ac.id 
KUHperdata." Dalam perjanjian kredit biasanya telah diperjanjikan dengan tegas bahwa apabila debitor wanprestasi maka kreditor berhak mengambil harta jaminan tersebut sebagai pelunasan debitor (verhaalsrech)." Salah satunya adalah jaminan terhadap pesawat udara." Dengan tegas ditunjuk oleh undang-undang berdasarkan ketentuan pasal 1171 KUHPerdata tersebut berarti bila seseorang akan memasang hipotik perjanjian pemasangan hipotik harus dibuat dalam akta resmi.",2

Seperti dalam hal hipotik atas kapal dimasa lalu yang mana perjanjian pemasangan atau pembenahannya harus dibuat oleh pejabat pembuat akta tanah (PPAT) setempat. Dalam praktinya pembuatan akta hipotik atas kapal dilaksanakan oleh pejabat pendaftar dan pencatat balik nama kapal atau yang sering disebut PB3K, hal ini sesuai dengan pasal 60 ayat (2) undang-undang pelayaran. Setelah mengkaji akta yang dibuat oleh PB3K ini, maka akta ini dirasa kurang melindungi dan mewakili kepentingan para pihak yaitu kreditor dan debitor sehingga nantinya berpotensi mengakibatkan minimnya perlindungan hukum. ${ }^{3}$

Berdasarkan hukum Indonesia notaris dikenal sebagai pejabat yang kewenangannya meliputi pembuatan akta-akta otentik. Kewenangan notaris ini menunjukan bahwa notaris mempunyai kemampuan dan pengetahuan yang komprehensif mengenai perbuatan hukum perdata khususnya dalam pembuatan suatu akta yang mampu melindungi pihak-pihak yang terlibat didalamnya." Selanjutnya berdasarkan ketentuan pasal 15 ayat (2) UUJN notaris berwenang pula:

a. Mengesahkan tanda tangan dan menetapkan kepastian tanggal surat dibawah tangan dengan mendaftarkan dalam buku khusus

b. Membukukan surat-surat di bawah tangan dengan mendaftakan dalam buku khsusus

c. Membuat copy dari surat di bawah tangan berupa salinan yang membuat uraian sebagaimana ditulis dan digambarkan dalam surat yang bersangkutan

d. Melakukan pengesahan kecocokan fotocopy dengan surat aslinya

e. Memberikan penyuluhan hukum sehubungan dengan pembuatan akta

f. Membuat akta yang berkaitan dengan pertanahan

g. Membuat risalah lelang

Berdasarkan ketentuan pasal 15 ayat (1) dan (2) UUJN diatas dapat dikatakan bahwa wewenang utama dari notaris adalah untuk membuat akta otentik." Melihat pada sifat hakekatnya suatu pesawat udara merupakan suatu benda bergerak (moveable property). Oleh karena itu yang pertama-tama menguasai suatu pesawat udara adalah pengaturan hukum keperdataan mengenai benda bergerak. Namun demikian untuk berbagai keoentingan khusus perundang-undangan ternyata menyimpang dari aturan hukum dan memberlakukan pada pesawat udara berbagai aturan hukum yang lazim diberlakukan pada benda tidak bergerak. Kecenderungan ini menimbulkan pendapat dikalangan ahli hukum untuk memberikan suatu exceptional status sebagai benda

\footnotetext{
${ }^{2}$ Siti Malikhun Badriyah, Problematika Pesawat Udara Sebagai Jaminan Pada Perjanjian Kredit Dalam Pengembangan Industri Penerbangan : Jurnal MMH, Jilid 43 No.4, Oktober (2014).

${ }^{3}$ Sembiring M.A.G, Jurnal SASI: Jurnal Terakreditasi Nasional SK.No.28/E/KPT/2009, Volume 25 Nomor 2, 155-159, (2019), Status Hukum Jaminan Pesawat Dalam Perkembangan Objek Jaminan di Indonesia, p-ISSN: 1693-0061, e-ISSN: 2614-2961.
} 
bergerak yang diatur secara khusus dan menamakan moveable property sui generis ini mneunjuk pada suatu sifat tersendiri dari kebendaan pesawat udara. ${ }^{4}$

Sifat karakteristik dari pesawat udara adalah karena pesawat udara diberi tanda nasionalitas suatu Negara tertentu." Dengan memnuhi persyaratan-persyaratan hukum nasional tentang pendaftaran publik, suatu Negara akan memberikan suatu tanda bukti nasionalitas yang dikenal dengan tanda kebangsaan (nationality marks) dan registrasi ( registration marks) kepada pesawat udara tersebut. Nasionalitas pesawat udara menunjuk kepada adanya hubungan khusus antara pesawat udara tersebut dengan Negara tertentu. Konsekuensi hukumnya adalah bahwa Negara tersebut berhak menerapkan hak-hak khusus yang dapat dinikmati pesawat udara tersebut hukum internasional.

Beberapa ahli hukum perdata berpendapat bahwa klasifikasi kebendaan dalam benda bergerak dan tidak bergerak sudah tidak sesuai lagi dengan kenyataan dan kebutuhan saat ini. Kecenderunganya adalah penggolongan benda dalam terdaftar dan tidak terdaftar. Hal ini dikarenakan perkembangan kewajiban untuk mendaftarkan beberapa tanda tertentu salah satunya adalah pesawat terbang dapat dikelompokan dalam register moveable property atau benda bergerak terdaftar alasannya: ${ }^{5}$

1. Pada suatu pesawat udara diberikan suatu tanda nasionalitas disertai kewajiban didaftarkan pada Negara tertentu

2. Untuk tujuan kepentingan perdata, pesawat udara tunduk pada persyaratan dapat di daftarkan dalam suatu register umum yang bersifat perdata.

3. Pada pesawat udara ditetapkan ketentuan khusus tentang perolehan (acquisition) dan pengasingan (alienation) yang tidak berlaku pada benda bergerak lainnya

4. Pesawat udara dapat dijaminan dengan suatu hipotik atau mortgage

5. Pesawat udara lazim tunduk pada pengaturan hukum tentang penahanan dan penyitaan (attachment) yang berbeda dengan benda bergerak lainnya.

6. Berlakunya aturan hukun tentang bantuan (assistance) pesawat udara yang menimbulkan hal bersifat kebendaan yang di tetapkan oleh undang-undang dan hak ini mempunyai kedudukan mendahului hak jaminan lain yang sudah terdaftar.

Status hukum suatu pesawat udara dalam hukum public menurut J.C.Cooper disebut legal quasi-personality terbukti dengan diberikannya suatu tanda kebangsaan atau nasionalitas dan tanda registrasi kepada pesawat udara menurut hukum nasional tertentu yang menanadakan pula adanya izin untuk membawa benda Negara tersebut. Suatu tanda nasionalitas diperoleh setelah dipenuhi berbagai persyaratan yang ditetapkan oleh Negara yang bersangkutan dan setelah didaftarkanya pesawat udara tersebut dalam daftar umum (register yang bersifat publik) yang dipergunakan bagi keperluan itu. Menurut hukum internasional public, konsep nasionalitas yang dimiliki oleh perseorangan bertitikan adanya suatu ikatan antara seorang individu tersebut memperoleh nasionalitas atau kewarganeragaraanya.

Berdasarkan asas dan prinsip hukum perdata internasional khususnya dan yang dianut oleh mayoritas Negara-negara di dunia pesawat terbang di golongkan sebagai

${ }^{4}$ H. Salim HS, Perkembangan Hukum Jaminan Di Indonesia: PT. Raja Grafindo Persada, Jakarta, 21, (2004)

${ }^{5}$ E.Saefullah Wiradipradja, Pengantar Hukum Udara dan Ruang Angkasa: PT Alumni, Bandung, p.77, (2014) 
benda tidak bergerak. Prinsip hukum ini berpengaruh kepada penetapan aturan hukum keperdataan yang berlaku bagi pesawat terbang sebagai objek jaminan yaitu antara lain dapat mempunyai hubungan dengan lembaga jaminan berupa hipotik (hyphoteek). Dibeberapa Negara maju lembaga jaminan pesawat terbang telah dilaksanakan ketentuan motgage. Ketentuan mengenai lembaga jaminan pesawat terbang diatur dalam pasal 9, 10, dan 12, undang-undang nomor 15 tahun 1992 tentang penerbangan megenai pendaftaran dan kebangsaan pesawat terbang serta lembaga jaminan pesawat terbang.

Dalam pasal 9 undang-undang penerbangan diatur bahwa pesawat terbang yang akan dioperasikan di Indonesia wajib mempunyai tanda pendaftaran Indonesia. Dalam hal ini tidak semua pesawat terbang dapat mempunyai tanda pendaftaran Indonesia kecuali pesawat terbang sipil yang tidak didaftarkan di Negara lain dan memenuhi salah satu ketentuan dan syarat dibawah ini:

1. Dimiliki oleh warga Negara Indonesia atau dimiliki oleh badan hukum Indonesia

2. Dimiliki oleh warga Negara asing atau badan hukum asing dan dioperasikan oleh warga Negara Indonesia atau badan hukum Indonesia untuk jangka waktu pemakaian minimal 2 (dua) tahun secara terus menerus berdasarkan suatu perjanjian sewa beli, sewa guna usaha, atau bentuk perjanjian lainnya

3. Dimiliki oleh istansi pemerintah

4. Dimiliki oleh lembaga tertentu yang diizinkan pemerintah

Secara khusus ketentuan mengenai pendaftaran pesawat terbang Angkatan Bersenjata Republik Indonesia dan pendaftaran pesawat terbang sipil diatur lebih lanjut dalam peraturan pemerintah. Selain tanda pendaftaran Indonesia sesuai dengan ketentuan dalam pasal 10 undang-undang penerbangan, pesawat terbang dan helicopter yang akan di operasikan di Indonesia wajib pula mempunyai tanda kebangsaan Indonesia. Tanda kebangsaan Indonesia akan diberikan kepada pesawat terbang dan helikopter yang telah mempunyai tanda pendaftaran Indonesia. Persyaratan dan tata cara memperoleh dan mencabut tanda kebangsaan Indonesia bagi pesawat terbang dan helikopter dan jenis-jenis tertentu dari pesawat terbang dan helikopter yang dapat dibebaskan dari kewajiban memiliki tanda kebangsaan Indonesia diatur lebih lanjut dalam peraturan pemerintah. ${ }^{6}$

Negara-negara di dunia memiliki perbendaan potensi baik dari segi sumber daya alam maupun teknologi, perbedaan potensi ini yang dimiliki masing-masing Negara telah membuat satu Negara dengan Negara lainnya menjadi saling ketergantungan dan akhirnya membuat kerja sama internasional untuk dapat memenuhi kebutuhan negaranya. Indonesia dalam rangka memenuhi kebutuhan Negara melakukan kerja sama internasional,baik dengan Negara lain secara langsung maupun melalui peran organisasi internasional. Kerja sama internasional tersebut biasanya dituangkan dalam bentuk instrument yang biasa disebut dengan perjanjian internasional, baik yang bersifat bilateral, regional, maupun multilateral. Pembuatan perjanjian internasional telah menjadi keseharian aktivitas bangsa dan Negara Indonesia. Berdasaran data yang tersimpan saat ini telah tercatat sekitar 3596 perjanjian internasional yang dibuat oleh Indonesia dengan Negara lain maupun dengan subjek hukum internasional lainnya. Perjanjian internasional merupakan salah satu sumber hukum internasional dan

6 Achmad Susetyo, Pudyo Bayu Hartawan, Pengikatan Jaminan Pesawat Terbang: Kasus Perbankan, (2009), 
Indonesia merupakan Negara yang cukup aktif dalam pembuatan perjanjian internsional. Namun demikian bukan berarti bahwa suatu perjanjian internasional dimana Indonesia menjadi pihak didalamnya dapat langsung berlaku di Indonesia. Berlakunya perjanjian internasional diwilayah suatu Negara berkaitan dengan kedudukan hukum internasional dalam hukum nasional Negara tersebut.

Terdapat beberapa perjanjian internasional yang belum dapat dilaksanakan disuatu Negara selama perjanjian internasional tersebut belum memiliki peraturan pelasksana walaupun sudah memiliki peraturan pelaksana maka perjanjian internasional tersebut dapat mengikat atau dan memiliki akibat hukum dan dapat dilaksanakan disuatu Negara. Hal tersebut terkait dengan bagaimana perjanjian internasional tersebut mengatur mengenai kewajiban Negara tersebut dalam mengimplementasikanya terkait dengan pembuaan perjanjian internasional setelah suatu Negara menandatangani suatu perjanjian internasional yaitu proses ratifikasi perjajian nasional.

Ratifikasi perjanjian internasional menimbulkan suatu konsekuensi yuridis bagi suatu Negara yang telah terikat dalam suatu perjanjian internasional. Konsekuensi yuridis tersebut diantaranya terkait dengaan pengaruh perjanjian internasional bagi suatu Negara setelah meratifikasi perjajian internasional dan juga melihat apakah perlu dibuat suatu undang-undang nasional maupun penyempurnaan terhadap peraturan perundang-undangan yang sudah ada sebagai implementasi perjanjian tersebut. berdasarkan uraian diatas, maka dapat dihadapkan dua pertanyaan penelitian: (1) Bagaimana konsekuensi dan implementasi pengikatan jaminan pesawat udara berdasarkan ratifikasi konvensi cape town 2001 bagi kreditor pemegang jaminan kebendaan pesawat udara apabila debitor wanprestasi? (2) Bagaimana upaya perlindungan hukum bagi kreditor terkait dengan eksekusi atas pengikatan jaminan pesawat udara berdasarkan ratifikasi konvensi cape town 2001 ?

\section{METODE}

Metode yang digunakan dalam penelitian ini adalah penelitian yuridis normative, suatu proses untuk menemukan aturan hukum, prinsi-prinsip hukum maupun doktrin-doktrin hukum guna menjawab isu-isu hukum yang dihadapi. Hal ini karakter perspektif ilmu hukum berbeda dengan penelitian yang dilakukan di dalam keilmuan yang bersifat deskriftif yang menguji kebenaran dan tidaknya suatu fakta yang disebabkan oleh suatu faktor tertentu, penelitian hukum dilakukan untuk menghasilkan argumentasi, teori atau konsep baru sebagai perskripsi dalam menyelesaikan masalah yang dihadapi. Jika pada keilmuan yang bersifat deskriptif jawaban yang diharapkan didalam penelitian hukum adalah right, appropriate, inappropriate, atau wrong. Dengan demikian dapat dikatakan bahwa hasil yang diperoleh didalam penelitia hukum sudang mengandung nilai. ${ }^{7}$

\footnotetext{
${ }^{7}$ Peter Mahmud Marzuki, Penelitian Hukum: Cetakan ke 11, Jakarta, Kencana, (2011)
} 


\section{PEMBAHASAN}

\section{A. Kerangka Teori}

\section{Teori Perlindungan Hukum}

Keberadaan hukum dalam masyarakat merupakan sautu sarana untuk menciptakan ketentraman dan ketertiban masyarakat, sehingga dalam hubungan antar anggota masyarakat yang satu dengan yang lainnya dapat dijaga kepentingannya, hukum tidak lain adalah perlindungan kepentingan manusia yang berbentuk norma dan kaidah. Hukum sebagai kumpulan peraturan atau kaidan yang mengandung isi yang bersifat umum dan normative, umum karena berlaku bagi setiap orang, dan normative karena menentukan bagaimana cara melaksanakan kepatuhan pada kaidah. Wujud dari peran hukum dalam masyarakat adalah memberikan perlindungan hukum kepada anggota masyarakat yang kepentingannya terganggu.

Persengketaan yang terjadi dalam masyarakat harus diselesaikan menurut hukum yang berlaku, sehingga dapat mencegah perilaku main hakim sendiri, tujuan pokok hukum sebagai perlindungan kepentngan manusia adalah menciptakan tatanan masyarakat yang tertib, sehingga terwujud kehidupan yang seimbang. Menurut Sudikno Mertokusumo bahwa hukum itu bertujuan tercapainya ketertiban dalam masyarakat sehingga diharapkan kepentingan manusia akan terlindungi untuk mencapai tujuannya dan bertugas membagi hak dan kewajiban antar perorangan dalam masyarakat membagi wewenang dan mengutamakan pemecahan masaah serta memelihara kepastian hukum.

Menurut Subekti dalam buku Sudikno Mertokusumo berpendapat bahwa tujuan hukum itu mengabdi kepada tujuan Negara yaitu mendatangkan kemakmuran dan kebahagiaan bagi rakyatnya. Pada hakekaatnya terdapat hubungan antara subjek hukum dengan hak dan kewajiban yang timbul dari gabungan hukum tersebut harus dilindungi oleh hukum, sehingga anggota masyarakat merasa aman dalam melaksanakan kepentingannya. Hal ini menunjukan bahwa perlindungan hukum dapat diartikan sebagai suatu pemberian jaminan atau kepastian bahwa seseorang akan mendapatkan apa yang telah menjadi hak dan kewajiban sehingga yang bersangkutan merasa aman. ${ }^{8}$ Bentuk perlindungan hukum eksekusi benda jaminan pada perjanjian jaminan kebendaan dapat dilaksanakan dengan serta merta karena tidak ada benda yang bisa dijadikan objek jaminan yang dapat dieksekusi.

\section{Teori Hukum Jaminan}

Hukum jaminan berasal dari terjemahan Zakerheidesstelling atau Security of Law. Menurut Sri Soedewi Masjhoen Sofwan ${ }^{9}$ mengemukakan bahwa hukum jaminan adalah mengatur kontruksi yuridis yang memungkinkan pemberian fasilitas kredit, dengan menjaminkan benda-benda yang dibelinya sebagai jaminan, peraturan demikian harus cukup meyakinkan dan memberikan kepastian hukum bagi lembagalembaga kredit, baik dalam negeri maupun luar negeri, dengan adanya lembaga kredit dengan jumlah besar dengan jangka waktu yang lama dan Bunga yang relative rendah.

\footnotetext{
${ }^{8}$ Niken Prasetyawati, Tony Hanoraga, jaminan Kebendaan dan Jaminan Perorangan Sebagai Upaya Perlindungan Hukum Bagi Pemilik Piutang: jsh Jurnal Sosial Humaniora, Vol 8 No.1, (2015),

9 Sri Soedewi Masjchoen Sofwan, Hukum Perdata : Hukum Benda, Penerbit Liberty, Yogyakarta, 103, (2000).
} 
Pernyataan ini merupakan sebuah konsep yuridis yang berkaitan dengan penyusunan peraturan perundang-undangan yang mengatur tentang jaminan pada masa yang akan dating. Saat ini telah dibuat berbagai peraturan perundang-undangan yang berkaitan dengan jaminan. Hukum jaminan merupakan ketentuan hukum yang mengatur hubungan hukum antara pemberi jaminan (debitur) dan penerima jaminan (kreditur) sebagai akibat pembebanan suatu utang tertentu dengan suatu jaminan, bahwa dalam hukum jaminan tidak hanya mengatur perlindungan hukum terhadap kreditur sebagai pihak pemberi hutang saja melainkan juga mengatur perlindungan hukum terhadap debitu sebagai pihak penerima hutang atau hukum jaminan tidak hanya mengatur hak-hak kreditur yang berkaitan dengan jaminan pelunasan utang tertentu namun sama-sama mengatur hak-hak kreditur dan hak-hak debitur yang berkaitan dengan jaminan pelunasan utang tertentu tersebut.

J.Satrio mengartikan hukum jaminan adalah "Peraturan hukum yang mengatur jaminan-jaminan piutang seorang kreditur terhadap debitur. Definisi ini difokuskan pada pengaturan pada hakekatnya kreditor semata-mmata, tetapi tidak memperhatikan hak-hak debitur. Berdasarkan berbagai kelemahan definisi tersebut perlu dilengkapi dan disempurnakan bahwa hukum jaminan adalah: "keseluruhan kaidah-kaidah hukum yang mengatur hubungan hukum antara pemberi dan penerima jaminan dalam kaitannya dengan pembebanan jaminan untuk mendapatkan fasilitas kredit." Sehubungan dengan pengertian hukum jaminan tidak banyak literature yang merumuskan pengertian hukum jaminan. Menurut J.Satrio hukum jaminan itu diartikan peraturan hukum yang mengatur tentang jaminan-jaminan piutang seorang kreditur terhadap seseorang debitur atau dengan kata lain hukum jaminan adalah hukum yang mengatur tentang jaminan piutang seseorang.

Definisi ini difokuskan pada pengaturan pada hak-hak kreditur semata-mata tetapi juga erat kaitannya dengan debitur. Sedangkan yang menjadiobjek kajiannya dalah benda jaminan. Menurut M.Bahsan hukum jaminan merupakan himpunan ketentuan yang mengatur atau berkaitan dengan penjaminan dalam rangka utang piutang (pinjaman uang) yang terdapat dalam berbagai peraturan perundang-undangan yang berlaku saat ini. Sementara itu, Salim H.S memberikan rumusan hukum jaminan adalah keseluruhan kaidah-kaidah hukum yang mengatur hubungan antara pemberi dan penerima jaminan dalam kaitannya dengan pembebanan jaminan untuk medapatkan fasilitas kredit.

\section{B. Konsekuensi dan Implementasi Pengikatan Jaminan Pesawat Udara Berdasarkan Ratifikasi Konvensi Cape Town 2001 bagi Kreditor Wanprestasi}

a) Konsekuensi Pengikatan Jaminan Pesawat Udara Berdasarkan Konvensi Cape Town Apabila Debitor Wanprestasi

Dalam UURI Np.83 tahun 1958 maupun UURI No.15 tahun 1992 persyaratan untuk memperoleh izin usaha angkutan udaraniaga tidak harus mempunyai jaminan bank(bank guarantee). Demikian pula dalam RUU penerbangan juga tidak ada usul persyaratan untuk memperoleh izin usaha angkutan usara harus mempunyai jaminan bank (bank guarantee). Hal ini berbeda dengan UURI No.1 tahun 2009 yang mensyaratkan untuk memperoleh izin usaha angkutan tersebut untuk memperoleh izin usaha angkutan udara niaga adalah garansi bank (bank guarantee). Persyaratan tersebut penting untuk menjamin kelangsungan hidup perusahaan penerbangan, dalam 
hal perusahaan penerbangan jatuh, maka bank diharapkan dapat menjamin semua tagihan dari kreditor dapat dibayar oleh bank, karena itu dalam pembahasan dengan Dewan Perwakilan Rakyat RI persyaratan jaminan bank (bank guarantee) yang diatur dalam Peraturan Menteri Perhubungan diangkat ke dalam UURI No.1 tahun 2009, menurut pasal 108 UURI No.1 tahun 2009 untuk memperoleh izin usaha angkutan udara niaga baik terjadwal (schedule airlines) maupun tidak terjadwal (non schedule airlines) harus mempunyai jaminan bank (bank guarantee) tidak hanya izin usaha angkutan usara niaga berjadwal maupun tidak terjadwal yang diharuskan adanya jaminan bank, bahkan izin usaha penunjang angkutan udara pun diharuskan adanya jaminan bank (bank guarantee). Masalah jaminan juga dikarenakan dalam hal pesawat udara melakukan penerbangan ke Amerika Serikat, perusahaan penerbangan tersebut wajib mengasuransikan tanggung jawabnya terhadap pihak ketiga. ${ }^{10}$

Cape Town Convention 2001 merupakan perjanjian internasional yang cukup penting dalam lingkup hukum udara dan hukum perdata internasional. Konvensi ini memberikan keuntungan secara ekonomis Negara yang meratifikasinya. Salah satunya bank ekspor impor Amerika Serikat yang menurunkan biaya dalam pembelian pesawat komersial yaitu sepertiga bagi pembeli asing yang berasal dari Negara yang telah meratifikasi dan mengimplementasikan cape town convention 2001. Tujuan dari cape town convention 2001 yang merupakan rekomendasi dari pemerintah Canada UNIDROIT adalah untuk melakukan harmonisasi hukum mengenai jaminan terhadap benda bergerak (Security Interest in mobile Equiment). Upaya ini dilakukan dengan mengirimkan kuisioner kepada individu dan lembaga mengenai dengan issue ini, yang menunjukan bahwa terdapat pendekatan yang bervariasi terkait dengan pengakuan jaminan terhadap benda bergerak yang berasal dari Negara lain. Pendekatan yang cukup berbeda antara satu dan Negara lain telah menimbulkan kesulittan bagi kreditor mengenai pengakuan dan pelaksanaan jaminan. Perbedaan inah yang menjadi dorongan terkuat untuk melakukan harmonisasi dalam bidang hukum ini. ${ }^{11}$

Dalam beberapa yuridiski kecuali Amerika Utara, hukum yang berlaku bagi benda adalah berdasarkan prinsip lex situs. Prinsip ini hanya dapat berlaku terhadap benda yang terasuk pada benda tetap, sedangkan begi benda bergerak tidak dapat digunakan, karena benda tersebut berpindah dari satu Negara ke Negara lain, permasalahan yang muncul adalah hak jaminan terhadap benda tersebut dapat diakui oleh Negara kedua dan biasanya hak jaminan ini hanya dapat diakui di wilayah asalnya aja. Perbedaan terhadap hak jaminan terhadap benda bergerak ini sangat jelas pada sistem hukum common law hak jaminan ini dapat diakui bahkan ketika berada di Negara kedua. Adapun pada sistem hukum civil law umumnya hak jaminan kebendaan hanyak diakuidi wilayah aslinya dan belum tentu bah hak jaminan ini bisa diakui di Negara kedua, hal ini tergantung bagaimana hukum nasional dari suatu Negara mengaturnya. ${ }^{12}$

Sistem hukum Eropa Kontinental atau civil law membatasi hak jaminan berdasarkan hukum nasionalnya. Adapun pengadilan common law lebih mudah untuk mengakomodir hak jaminan asing karena adanya pendekatan yang flexible berdasarkan persamaan persyaratan hak jaminan. Kegunaan dari sistem eropa

\footnotetext{
${ }^{10}$ K. Martono, Amad Sudiro, Hukum Angkatan Udara, Berdasarkan UU RI No.1 Tahun 2009, Rajawali Pers, Divisi Buku Perguruan Tinggi PT RajaGrafindo Persada, Jakarta, p 22, (2010).

${ }^{11}$ Prita Amalia, Industri Penerbangan di Indonesia, Aspek Hukum Pasca Cape Town Convention 2001, PT Refika Aditama: Bandung, p.55,(2016).

12 Ibid, p.46
} 
continental adalah dengan tidak mengakui jaminan asing terhadap benda bergerak di Negara kedua. Dalam lingkup pembiayaan pesawat udara secara internasional sebelumnya sudah terdapat kerangka hukum yang dikenal dengan Geneva Convention 1998 tentang pengakuan internasional atas hak-hak pada pesawat udara, namun dalam beberapa hal tidak sama dengan hipotik, gadai dan hak pesawat udara yang sejenis diatur dalam hukum nasional dan penerapan hak-hak ini secara lintas batas, khususnya di pengadilan asing yang diatur secara berbeda untuk pesawat udara komersial.Lebih lanjut dengan tidak adanya sistem pendaftaran secara terpusat telah menimbulkan kesulitan untuk memberikan informasi mengenai hak pesawat udara yang didaftarkan, mengenai kreditor dan juga detailnya. Oleh karena itu, ketika ide untuk membuat instrument hukum internasional untuk menciptakan pengakuan internasional mengenai kepentingan internasional dan pendaftaran internasional terpusat diajukan mendapat perhatian yang cukup, khususnya dalam lingkup hukum udara internasional. ${ }^{13}$

Cape town convention 2001 merupakan intrumen hukum hasil kerja sama dan usaha ICAO dan UNIFROIT, dan juga dua lembaga non pemerintah yang ewakili industry penerbangan yaitu IATA (International Air Transport Accociation) dan AWG (Aviation Working Group). Kepentingan industry untuk menciptakan kerangka hukum baru untuk kepentingan internasional dalam peralatan pesawat udara dan pendaftaran internasional dilaterbelakangi dengan tujuan untuk mengurangi biaya pembelian pesawat udara melalui di turunkannya risiko pinjaman dan untuk mengurangi biaya transaksi lainnya. Kepentingan pemerintah dengan harapan untuk mendukung industry, melalui dikuranginya biaya pengadaan pesawat udara untuk pemerintah dan keinginan untuk menurunkan langsung terhadap neraca keuangan pemerintah.

Cape Town Convention 2001 terbentuk dari beberapa group yang ada di UNIDROIT, yang dimulai pada awal tahun 1990 dan ICAO bergabung dengan UNIDROIT untuk merumuska konvensi ini pada tahun 1997. Setelah melewati beberapa kali konfrensi diplomatik, maka pada tanggal 16 November 2001 di Cape Town, Afrika Selatan menghasilkan dua instrument, yaitu "Convention on International Interest in Mobile Equipment on Matters specific Aircraft Equipment." Dalam membuat cape town convention 2001, perumus dihadapkan pada suatu masalah untuk untuk menyusun bahasa yang dapat digunakan untuk semua katagori peralatan sehingga memberikan kekhususan sesuai dengan karakteristik dari peralatan tersebut. Dengan demikian, ketentuan yang terdapat dalam konvensi merupakan suatu ketentuan paying (umbrella provision) yang mengatur mengenai prinsip-prinsip umum untuk semua peralatan yang akan dijelaskan lebih lanjut dalam protokol. ${ }^{14}$

Protokol memiliki fungsi control terhadap implementasi konvensi. Penyusunan konvensi menyadari bahwa proyek ini merupakan proyek yang cukup luas yang hanya dapat dibatasi pada peralatan yang memiliki nilai tinggi secara internasional. Terdapat persyaratan minimum yang harus dipenuhi dalam mengaplikasikan konvensi ini, yaitu:

1. Adanya kepentingan internasional, berdasarkan keadaan di bawah ini:

13 K. Martono, Amad Sudiro, Hukum Udara Publik, Nasional dan Internasional: PT RajaGrafindo Persada, Jakarta, p.233, (2012)

${ }^{14}$ Motjaba Eshraghi Arani, The Legal Impediments to the accession of iran to the cape town convention on international interest in mobile equipment and aircraft protocol, Uniform Law Review, Volume 24m Issue 1, March 2019, Pages 243-253, https://doing.org/10.1093/ulr/unz010 
a) kepentingan internasional / jaminan berdasarkan perjanjian jaminan

b) kepentingan internasional / jaminan dari conditional seller berdasarkan reservation agreement

c) kepentingaan internasional / jaminan yang dimiliki lessor berdasarkan perjanjian leasing

2. Syarat formal untuk kepentingan internasional

a) Diajukan secara tertulisb.

b) Harus berkaitan dengan objek yang dimiliki oleh penjamin, penjual dalam jual beli bersyarat atau lessor yang memiliki kewenangan untuk terikat pada suatu kontrak.

c) objek yang merupakan subjek dari perjanjian harus dapat diidentifikasi

d) kewajiban yang timbul dari perjanjian harus dapat di identifikasi

Dalam hal dibuatnya kontrak, debitur harus berasal dari Negara yang menandatangani konvensi begitu juga dengan kreditur. Konvensi hanya berlaku pada peralatan pesawat udara, peralatan kereta api, dan asset ruang angkasa. Kepentingan internasional berdasarkan konvensi merupakan suatu ketentuan yang terpisah dan tidak memerlukan atau berhubungan dengan hukum nasional. Cape Town Convention 2001 dibuat untuk memenuhi lima tujuan yaitu: ${ }^{15}$

a) untuk mencapai pengakuan kepentingan internasional di seluruh Negara anggota

b) untuk memberikan bantuan kepada debitur, ketika terjadi gagal bayar untuk menentukan tindakan yang dilakukan dengan cepat

c) untuk mendirikan pendaftaran internasional elektronik untuk pendaftaran kepentingan internasional

d) d. untuk menjamin melalui protokol adanya suatu keperluan khusus terhadap sektor industry tertentu

e) untuk memberikan kepercayaan diri pada kreditor untuk mengambil keputusan dalam memberikan kredit dengan meningkatkan pemberian kredit terhadap peralatan tersebut dan menurunkan biaya pinjaman

Selain tujuan diatas, konvensi dan protokol memiliki tujuan yang sangat objektif dan tidak semuanya dalam ingkup lembaga pembiayaan jaminan, yang sebagian besar akan diatur lebih lanjut dalam hukum nasiona dan perjanjian diantara para pihak. Seperti telah dijelaskan diatas, bahwa konvensi tidak mengatur secara spesifik mengenai peralatan yang dimaksud. Konvensi akan berlaku secara sama terhadap tiga katagori peralatan, sehingga konvensi tidak akan berlaku terhadap suatu katagori peralatan sampai protokol dari konvensi yang berkaitan dengan peralatan tersebut selesao tersusun. Ketika terjadi inkonsistensi antara konvensi dan protokol, maka ketentuan dalam protokol akan digunakan.

Cape Town Convention 2001 mengandung lima prinsip dibawah ini yaitu: ${ }^{16}$

${ }^{15}$ Amalia P, Budhijanto S, Adolf H, Chandawulan A, The Development of Private international law: a new concept of mobile equipment under the cape town convention 2001, Journal of legal, Ethical and regulatory issues (2009), 22 (40)

${ }^{16}$ Teresa Rodriguez de las Heras Ballell, Complexities ariing form the expansion of the cape town convention to other sectors : the MAS protocol's challenges and innovative solutions, Uniform Law Review, Volume 23, Issue 2, June 2008, Pages 214-241, https://doi.org/10.1093/url/uny017 
1. Praciticality: Dalam mencerminkan faktor-faktor penting dalam pembiayaan berbasis dan transaksi leasing (sewa beli) dan asset based financing

2. Party autonomy: dalam hubungan berdasarkan kontrak, mencerminkan fakta bahwa para pihak dalam transaksi lintas batas yang bernilai tinggi terkait dengan peralatan yang menjadi lingkup dalam konvensi ini adalah pihak yang memiliki pengetahuan dan pengalaman dalam transaksi tersebut sehingga perjanjian diantara mereka harus dihormati dan ditegakan

3. Predictability : dalam menetapkan konvensi khususnya, direfleksikan secara singkat dan aturan yang jelas dengan memberikan kepastian, kesederhanaan dan pendekatan yang berdasakan ketentuan disbanding pendekatan standar.

4. Transparancy : melalui aturan yang mengatur pendaftaran dari kepentngan internasional untuk memberitahukan kepada pihak ketiga dimana kepentingan internasional beum didaftarakan untuk melakukan pendaftaran kepentingan internasional dan juga hak dari pembeli

5. Sensitivity : terhadap budaya hukum nasional Negara peserta dengan mempertimbangkan keuntungan ekonomi untuk menciptakan ketentuan hukum nasional dan membuat deklarasi (a) untuk meniadakan, sebagian atau seluruh ketentuan dari konvensi dengan mempertimbangkan bahwa ketentuan tersebut tidak sesuai dengan prinsip hukum nasionalnya atau (b) untuk mengikatkan diri pada suatu ketentuan dari konvensi yang sejalan dengan prinsip hukum nasionalnya.

Selain prinsip-prinsip tersebut yang mendasari berlakunya cape town convention 2001, konvensi ini juga membagi perlindungan jaminan yang terbagi dalam lima katagori yaitu:

1. International interest (kepentingan internasional) : international interest (kepentingan internasional) merupakan jaminan yang dijaminkan oleh charger berdasarkan perjanjian jaminan (security agreement), reservation agreement (perjanjian bersyarat) atau oleh lessor berdasarkan perjanjian leasing, selain jaminan lainnya yang timbul dari transaksi dalam negeri. Kepentingan internasional merupakan katagori yang utama dalam penerapan cape town convention 2001

2. Propective international interest merupakan jaminan yang belum merupakan kepentingan internasional sepenuhnya. Prospective international interest akan dipelakukan sama halnya dengan kepentingan internasional apabila syaratnya telah dipenuhi.

3. National interest (kepentingan nasional) merupakan jaminan yang didaftarkan berdasarkan hukum nasional yang dapat dimungkinkan didaftarkan sebagai kepentingan internasional yang harus memperhatikan deklarasi yang dilakukan oleh Negara penandatanganan sesuai Pasa; $50^{17}$ yang mengecualikan beberapa ketentuan dalam konvensi

\section{${ }^{17}$ Article 50 - internal transaction}

1. A. contracting state may, at the time of ratification, acceptance approval if, or accession to the protocol, declare tahta this convention shall not apply to a transactoion which is an internal transaction in telation to that state with regard to all types of object or some of them

2. notwhitsatnding the preceding paragraph, the provision of Articles 8 (4), 9 (1), 16 chapter V, Article 29 and any provisions of this convention relating to registraes intersrt shall apply to ann internal transaction

Where notice of a national interest has beebn registrate in the international registry, the priority of the holder of that interest under article 29 shall not e aafected by the fact that such interest has becomevested in another person by assignment or subrogation under the applicable law 
4. Registrable non consensual right or interes arising under national law, Negara peserta konvensi dimungkinkan membuat deklarasi berdasarkan Pasal 40, ${ }^{18}$ untuk non consensual right berdasarkan hukum nasionalnya dapat didaftarkan melalui pendaftaran internasional dan hak yang didaftarkan tersebut mendapat perlakuan layaknya kepentingan internasional yang didaftarkan secara internasional

5. Non consensual right or interest arising under national law and given priority without registration, Negara peserta konvensi dapat membuat deklarasi berdasarkan pasal 39. ${ }^{19}$

Selain sistem pendaftaran internasional yang diatur dalam cape town convention 2001 dan menjadi perhatian baik kreditur maupun debitur, hal lainya yang menarik adalah terkait dengan prioritas (priority rules). Dengan adanya sistem pendaftaran internasional, maka jaminan yang didaftarakan memiliki prioritas dibandingkan dengan jaminan yang tidak didaftarkan (unregistered interest dan juga jaminan yang didaftarkan kemudia. Ketentuan lain yang juga penting dalam cape town convention 2001 adalah upaya pemulihan (default remadies). Konvensi mengatur hak pemulihan apabila dikemudian hari terjadi wanprestasi berdasarkan suatu perjanjian pengadaan pesawat udara termasuk perjanjian sewa beli (lease agreement). Ketika suatu Negara masih menggunakan hukum nasionalnya dalam upaya pemulihan ini, maka dapat dikatakan bahwa cape town convention 2001 belum sepenuhnya berlaku, karena ketentuan pemulihan ini merupakan suatu ketentuan yang bersifat wajib (mandatory).

Beberapa upaya pemulihan yang dapat dilakukan diantara hak untuk mengambil penguasaan atau pengendalian atas objek tersebut. Untuk melaksanakan upaya pemulihan ini Negara dapat menetapkan apakah diperlukan permohonan kepada pengadilan untuk melaksanakan hak pemulihan (remedies) tersebut. Mengenai upaya pemulihan ini (default remedies) diatur dalam Chapter III dari cape town convention 2001. Terkait dengan pesawat udara, protokol juga mengatur secara spesifik upaya pemulihan apabila terjadi wanprestasi. Pasal IX mengatur bahwa kreditur dapat meminta penghapusan pendaftaran pesawat udara dan meminta dilakuan ekspor dan transfer pesawat udara di wilayah dimana objek tersebut berada.

Indonesia merupakan salah satu Negara yang meratifikasi Cape Town Convention 2001 melalui Peraturan Presiden Republic Indonesia Nomor 8 tahun 2007 tentang Pengesahan Convention on International Interest in Mobile Equipment (konvensi

\footnotetext{
${ }^{18}$ Article 40- Registable non concensual rights or interest, A contracting state may at any time in a declaration deposited with the depository of the protocol list the catagories of non consensusal right or interest which shall be registrable under this convention as regard any category of object as if the right or interest wewe an international interest and shall be regulated accordingly. Such a declaration may be modified from time to time

${ }^{19}$ Article 39- right having priority without registration

(1). A contracting state may at any time, in a declaration deposited with the depositary of the protocol declare, generally of specifically,

(a) those catagories of non-consensual right or interest (other than a right on interest to which article 40) which under that state 'law have priority over an interest and which shall have priority over a registered international interest, whether in or outside insolvency procceding; and

(b) that nothing in this convention shall affect the right of a state wntity, intergovernmental organization or other private provider of public service to arrest or detain an object under the laws of that state for payment of amounts owed to such entity, organization or provide dereclty relating to those service in respect of that object or another object
} 
tentang kepentingan internasional dalam peraatan begerak) beserta Protocol to the Convention on International Interest in Mobile Equipment on Matters Specific to Aircraft Equipment (protokol pada konvensi tentang kepentingan khsusus pada peralatan pesawat udara). Indonesia meratifikasinya sesuai dengan ketentuan ratifikasi yang diatur dalam pasal $11^{20}$ Undang-Undang Dasar Republik Indonesia tahun 1945, serta memperhatikan ketentuan ratifikasi perjanjian internasional yang diatur dalam undang-undang perjanjian internasional yaitu pasal $4 .{ }^{21}$

\section{Perlindungan Hukum bagi Kreditor dengan Eksekusi Pengikatan Jaminan Pesawat Udara Berdasarkan Ratifikasi Konvensi Cape Town 2001}

\section{Tinjauan Umum tentang Eksekusi}

Istilah eksekusi apabila diterjemahkan ke dalam bahasa Indonesia dapat diartikan sebagai pelaksanaan keputusan " melakukan atau melaksanakan secara paksa putusan pengadilan dengan bantuan kekuatan umum apabila pihak yang kalah (tereksekusi tidak mau menjalankan putusan itu dengan sukarela." Asas-asas eksekusi dapat di lihat pada putusan yang memperoleh kekuatan hukum tetap (in krach van gewiksde) bagi tuntutan dari penggugat terhadap tergugat dalam suatu persidangan, dalam hal ini kedudukan tergugat berubah menjadi pihak yang tereksekusi (pihak yang kalah). Namun tidak semua putusanpengadilan mempunyai kekuatan hukum eksekutorial artinya tidak terhadap putusan-putusan dengan sendirinya melekat kekuatan pelaksanaan berarti tidak semua putusan pengadilan yang dapat dieksekusi.

- Cara melaksanakan eksekusi hipotik

Dalam hal debitur wanprestasi dan setelah diberi peringatan tetap tidak mau memnuhi kewajiban, maka debitur pemegang hipotik disediakan 3 (tiga) prosedur eksekusi yaitu:

1. Melalui pengajuan gugatan perdata biasa pada pengadilan negeri

2. Menggunakan ketentuan pasal $224 \mathrm{RIB} / 258 \mathrm{RBg}$

3. Menggunakan kewenangan yang diatur dalam pasal 1178 ayat 2 KUHPerdata

\footnotetext{
${ }^{20}$ Pasal 11 UUD 1945

1.presiden dengan persetujuan Dewan Perwakilan Rkyat menyatakan perang membuang perdamaian dan perjanjian dengan Negara lain

2.presiden dalam membuat perjanjian internasional lainnya yang menimbulkan akibat yang luas dan mendasar bagi kehidupan rakyat yang terkait dengan beban keuangan Negara, dan /atau mengharuskan perubahan atau pembentukan undang-undang harus dengan persetujuan Dewan Perwwakilan Rakyat

3.ketentuan lebih lanjut tentang perjanjian internasional diatur oleh Undang-Undang

${ }^{21}$ Pasal 4 Undang-Undang Perjanjian internasional

1.pemerintah Republik Indonesia membuat perjanjian internasional dengan satu Negara atau lebih, organisasi internasional atau subjek hukum internasional lain berdasarkan kesepakatan dan para pihak berkewajiban untuk melaksanakan perjanjian tersebut dengan itikad baik

2.dalam membuat perjanjian internasional, Pemerintah Republik Indonesia berpedoman pada kepentingan nasional berdasarkan prinsip-prinsip persamaan kedudukan, slaing menguntungkan dan memperhatikan baik hukum nasional maupun hukum internasional yang berlaku
} 
Seperti kreditur yang lain pemegang hipotik dapat mengajukan gugatan perdata bisa pada pengadilan negeri untuk memperoleh keputusan pengadilan yang memerintahkan debitur untuk memenuhi kewajibannya. Jika sekalipun sudah ada keputusan pengadilan yang mempunyai kekuatan untuk dilaksanakan, debitur tetap tidak melunasi utangnya, maka pelaksanaan putusan tersebut dilakukan atas perintah dan dengan pimpinan ketua pengadilan negeri yang bersangkutan, atas perintah ketua pengadilan itu dilakukan pensitaan atas tanah yang dijadikan jaminan untuk kemudian dilelang dengan perantara kantor lelang. Dari hasil pelelangan itu kreditur memperoleh pelunasan utangnya dengan hak mendahuu dari pada kreditur-kreditur lain yang tidak mempunyai hak preferen dari padanya. Kelemahan prosedur ini adalah bahwa penyelesaianya memerlukan waktu, setelah diperoleh keputusan dari pengadilan negeri kemudian mengajukan kasasi pada mahkamah agung. ${ }^{22}$

Bahkan ada juga kreditur yang setelah ada putusan pada tingkat kasasi, masih menggunakan upaya hukum yang lain, yaitu peninjauan kembali. ." Dalam pada itu bagi kreditur memang masih tersedia upaya untuk memperoleh kembali piutangnya, tanpa harus menunggu sampai diperoleh putusan Mahkamah Agung yang berkekuatan tetap. la dapat mohon agar Pengadilan Negeri dalam putusannya menentukan bahwa putusan itu dapat diIaksanakan dengan "serta merta" ("Uitvoerbaar bij voorraad"), karena gugatannya didasarkan pada akta otentik dan bukti-bukti lain yang diisyaratkan dalam pasal $180 \mathrm{RIB}$, biarpun debitur naik banding. Untuk mengeksekusi putusan serta merta itu perlu diperoleh terlebih dahulu izin dari Pengadilan Tinggi dan/atau Mahkamah Agung. Tetapi sekalipun sudah diperoleh putusan Pengadilan yang mengabulkan gugatannya, belum tentu pelaksanaannya akan membawa hasil memuaskan. Eksekusi Hipotik dengan menggunakan ketentuan pasal 224 RIB atau pasal $258 \mathrm{RBg} .{ }^{23} \quad$ Pasal224 RIB dan pasal $258 \mathrm{Rbg}$ menyatakan, bahwa kepada grosse akta Hipotik, yang pada kepalanya dicantumkan kata-kata "Atas Nama Baginda Raja" (sekarang tentunya " Demi Keadilan Berdasarkan Ketuhanan Yang Maha Esa") diberikan kekuatan yang sarna seperti putusan Pengadilan. Jika tidak dapat diselesaikan secara damai, pelaksanaannya dilakukan atas perintah dan dengan pimpinan Ketua Landraad Atas permintaan kreditur pemegang Grosse akta Hipotik, Ketua Pengadllan Negeri akan memberi perintah kepada debitur untuk memenuhi kewajibannya. Jika debitur metigabaikan perintah tersebut, Ketua . Pengadilan Negeri akan memberi "fiat" eksekusi dan memerintahkan pensitaan tanah yang dijadikan jaminan, untuk kemudian di jual lelang untuk memperoieh pelunasan bagi piutang kreditur. Aeara yang dikenal dengan sebutan "Parate Exeeutie" ini tidak perlu didahului dengan pengajuan gugatan perdata. Tetapi aeara ini hanya dapat digunakan, kalau mengenai piutang kreditur yang bersangklitan tidak ada sengketa. Kalau debitur menyangkal, bahwa ia masih mempunyai hutang pada kreditur atau besarnya piutang dipermasalahkan, Ketua Pengadilan Negeri akan menolak memerintahkan eksekusinya. Dalam hal demikian maka yang dihadapi adalah perkara utang piutang, yang penyelesaiannya harus meialui gugatan perdata. Eksekusi Hipotik dengan

${ }^{22}$ Boedi Harsono, Ketentuan Hukum Mengenai Eksekusi Hipotik Dalam Rangka Pendaftaran Menurut Overschrijingsordonantie 1834, Peraturan Pemerintah Nomor 10/1961 dan Undang-Undang Nomor 16/1985: Disampaikan pada Lokakarya Eksekusi Hipotik Dan Kepastian Hukumnya. Kerjasama FH VI dengan Radan Penanahan Nasional, mnggai 18 September 1990 di Golden Ballroom Hillon Hotel, Jakarta. Jurnal Hukum dan pembangunan Vol 20 No.6, (1990),

23 Mura P. Hutagalung, Eksekusi Hipotik Dan Kepastian Hukumnya: Jurnal Hukum dan Pembangunan, (1990), 
menggunakan kewenangan kreditur yang diatur dalam pasal 1178 ayat 2 KUHPerdata Indonesia. ${ }^{24}$

Ini adalah bentuk perlindungan eksekusi yang paling mudah, karena pelaksanaannya tidak memerlukan "fiat", persetujuan atau bantuan Ketua Pengadilan Negeri, dan dapat dilaksanakan sendiri oleh kreditur pemegang Hipotik pertama. Dalam pasal 1178 ayat 2 KUHPerdata Indonesia dinyatakan, bahwa dalam pembebanan Hipotik dapat diperjanjikan bahwa jika debitur eidera janji, kreditur seeara mutlak dikuasakan untuk menjual leiang tanah yang dibebani Hlpotik, yang hasilnya akan digunakan sebagai pelunasan piutang kreditur. Janji tersebut harus dinyatakan secara tegas dan didaftar pada "daftar umum". Pelelangannya harus dilakukan menurut ketentuan pasal1211 . Janji itupun hanya berlaku bagi pemegang Hipotik pertama. Dalam praktek janji tersebut seialu dimuat dalam akta pemberian Hipotik yang bersangkutan. Dan tidak terbatas pada pemberian Hipotik pertama, karena ada kemungkinan, bahwa Hipotik kedua dan seianjutnya kemudian akan bergeser naik menjadi Hipotik pertama, setelah piutang kreditur pemegang Hipotik pertama dilunasi. Janji atau beding irii dikenal sebagai: "beding van eigenmaehtige verkoop". ${ }^{25}$ Ada yang menalsirkan, bahwa dalam meiakukan eksekusi berdasarkan beding itu, kreditur bertindak atas kekuasaan sendiri, yang bersumber pada pasai 1178 ayat 2 terse but. Adapula yang menafsirkan bahwa ia bertindak selaku kuasa dari pemberi Hipotik. Tafsiran tersebut tentunya masing-masing ada konsekuensi yuridisnya. Tetapi bagaimanapun" ketentuan pasal 1178 ayat 2 tersebut bisa digunakan, hanya jika piuiang yang dituntut peiunasannya tidak disengketakan. 'Saransaran Pelaksanaan/penggunaan aeara eksekusi menurut pasal224 RIB1258 RBg dan pasal 1178 ayat 2 KUHPerdata Indonesia.

\section{KESIMPULAN}

Mengenai upaya pemulihan (default remedies) dalam cape town convention 2001 terkait dengan pesawat udara mengatur secara lebih spesifik menganai upaya pemulihan apabila terjadi wanprestasi. Pasal IX mengatur bahwa kreditur dapat meminta penghapusan pendaftaran pesawat udara dan meminta dilakukan ekspor dan transfer pesawat udara di wilayah dimana objek tersebut berada.

Pada prinsipnya setiap eksekusi harus dilaksanakan dengan melalui pelelangan umum, karena dengan cara ini diharapkan dapat memperoleh harga yang paling tinggi untuk objek hipotik. Sampai saat pengumuman untuk lelang dikeluarkan, penjualan (pelelangan) objek hipotik tersebut dapat dihindari dengan cara melunasi utang yang dijamin dengan hipotik itu beserta biaya-biaya eksekusi yang telah dikeluarkan

\section{SARAN}

Konvensi Cape Town 2001 mengatur upaya pemulihan (default remedies) apabila dikemudian hari terjadi wanprestasi berdasarkan suatu perjajian pengadaan pesawat udara termasuk perjanjian sewa beli (lease agreement). Ketika suatu Negara masih menggunakan hukum nasionalnya dalam upaya pemulihan maka dapat dikatakan bahwa cape town convention 2001 belum sepenuhnya belrkau, karena ketentuan ini

\footnotetext{
${ }^{24}$ Ibid, p.576-578

${ }^{25}$ Riki Rustam, Hukum Jaminan, UII Press, Yogyakarta, p.179-180, (2017)
} 
upaya pemulihan merupakan suatu ketentuan yang wajib.

Setelah dilakukannya eksekusi, kreditor pemegang hipotik berhak untuk mengambil pelunasan piutang yang dijamian dari hasil penjualan objek hipotik tersebut. Jika hasil penjualan eksekusi itu lebih besar dari pada piutang maka sisa hasil penjualan itu menjadi hak pemberi hipotik

\section{DAFTAR PUSTAKA}

\section{Buku}

E.Saefullah Wiradipradja, Pengantar Hukum Udara dan Ruang Angkasa: PT Alumni, Bandung, (2014)

H. Salim HS, Perkembangan Hukum Jaminan Di Indonesia: PT. Raja Grafindo Persada, Jakarta, (2004)

K. Martono, Amad Sudiro, Hukum Angkatan Udara, Berdasarkan UU RI No.1 Tahun 2009, Rajawali Pers, Divisi Buku Perguruan Tinggi PT RajaGrafindo Persada, Jakarta, p (2010).

K. Martono, Amad Sudiro, Hukum Udara Publik, Nasional dan Internasional: PT RajaGrafindo Persada, Jakarta, (2012)

Peter Mahmud Marzuki, Penelitian Hukum: Cetakan ke 11, Jakarta, Kencana, (2011)

Prita Amalia, Industri Penerbangan di Indonesia, Aspek Hukum Pasca Cape Town Convention 2001, PT Refika Aditama: Bandung, (2016).

Sri Soedewi Masjchoen Sofwan, Hukum Perdata : Hukum Benda, Penerbit Liberty, Yogyakarta, (2000).

\section{Jurnal}

Achmad Susetyo, Pudyo Bayu Hartawan, Pengikatan Jaminan Pesawat Terbang: Kasus Perbankan, (2009),

Amalia $\mathrm{P}$, Budhijanto $\mathrm{S}$, Adolf $\mathrm{H}$, Chandawulan A, The Development of Private international law: a new concept of mobile equipment under the cape town convention 2001, Journal of legal, Ethical and regulatory issues (2009), (40)

Boedi Harsono, Ketentuan Hukum Mengenai Eksekusi Hipotik Dalam Rangka Pendaftaran Menurut Overschrijingsordonantie 1834, Peraturan Pemerintah Nomor 10/1961 dan Undang-Undang Nomor 16/1985: Disampaikan pada Lokakarya Eksekusi Hipotik Dan Kepastian Hukumnya. Kerjasama FH VI dengan Radan Penanahan Nasional, mnggai 18 September 1990 di Golden Ballroom Hillon Hotel, Jakarta. Jurnal Hukum dan pembangunan Vol 20 No.6, (1990), 
I Nyoman Ganang Bayu Weda, I Made Sarjana, Suatra Putrawan, Jurnal Kertha Semaya: Vol.02, No.06 (2014), Pengaturan Pesawat Udara Sebagai Obyek Jaminan Kredit, E-ISSN: 2303-0569, https://ojs.unud.ac.id

Muhammad Waliyullah, Tinjauan Yuridis Pesawat Terbang Sebagai Objek Jaminan Hipotik DI Dalam Undang-Undang Nomor 1 Tahun 2009 Tentang Penerbangan: ETD Unsyiah online electronic theses and dissertations, (2018), https://etd.unsyiah.ac.id/

Mura P. Hutagalung, Eksekusi Hipotik Dan Kepastian Hukumnya: Jurnal Hukum dan Pembangunan, (1990),

Motjaba Eshraghi Arani, The Legal Impediments to the accession of iran to the cape town convention on international interest in mobile equipment and aircraft protocol, Uniform Law Review, Volume 24m Issue 1, March 2019, Pages https://doing.org/10.1093/ulr/unz010

Niken Prasetyawati, Tony Hanoraga, jaminan Kebendaan dan Jaminan Perorangan Sebagai Upaya Perlindungan Hukum Bagi Pemilik Piutang: jsh Jurnal Sosial Humaniora, Vol 8 No.1, (2015),

Priyatna Abdurrasyid, Ketiadaan Aturan Yang Jelas, Implementasi Hipotik Pesawat Terhambat, Hukum Online, (2004), https://www.hukumonline.com/

Sembiring M.A.G, Jurnal SASI: Jurnal Terakreditasi Nasional SK.No.28/E/KPT/2009, Volume 25 Nomor 2, 155-159, (2019),

Status Hukum Jaminan Pesawat Dalam Perkembangan Objek Jaminan di Indonesia, p-ISSN: 1693-0061, e-ISSN: 2614-2961.

Siti Malikhun Badriyah, Problematika Pesawat Udara Sebagai Jaminan Pada Perjanjian Kredit Dalam Pengembangan Industri Penerbangan : Jurnal MMH, Jilid 43 No.4, Oktober (2014).

Teresa Rodriguez de las Heras Ballell, Complexities ariing form the expansion of the cape town convention to other sectors : the MAS protocol's challenges and innovative solutions, Uniform Law Review, Volume 23, Issue 2, June 2008, Pages 214-241, https://doi.org/10.1093/url/uny017

\section{Undang-Undang}

Undang-Undang Dasar RI 1945

Undang-Undang Perjanjian Internasional

Kitab Undang-Undang Hukum Perdata

Protokol Konvensi Cape Town 2001 